\title{
POLITIK HUKUM PERLINDUNGAN NON-DEROGABLE RIGHTS PEKERJA MIGRAN INDONESIA TIDAK BERDOKUMEN
}

\author{
Ayuk Hardani \\ Fakultas Hukum Universitas Diponegoro \\ Korespondensi: arda.ayukhardani@gmail.com \\ Rahayu \\ Fakultas Hukum Universitas Diponegoro
}

\begin{abstract}
Abstrak
Pelanggaran terhadap hak-hak asasi manusia Pekerja Migran Indonesia tidak berdokumen masih terjadi hingga saat ini. Padahal peraturan hukum nasional memberikan jaminan perlindungan terhadap hak asasi manusia khususnya non-derogable rights. Artikel ini bertujuan untuk mengkaji politik hukum Indonesia dalam memberikan perlindungan nonderogable rights bagi pekerja migran Indonesia yang tidak berdokumen. Metode penelitian menggunakan penelitian yuridis normatif. Hasil penelitian ini menunjukkan bahwa pemerintah belum memberikan perlindungan optimal kepada Pekerja Migran Indonesia tidak berdokumen, politik hukum pemerintah lebih mengoptimalkan pada upaya pencegahan dari hulu hingga hilir. Negara dan pemerintah seharusnya berkewajiban menghormati, melindungi dan memenuhi hak-hak asasi manusia warga negara Indonesianya, khususnya non-derogable rights.
\end{abstract}

Kata Kunci: Politik Hukum, Non-derogable Rights, Pekerja Migran Indonesia Tidak Berdokumen.

\begin{abstract}
Violations of undocumented human rights of Indonesian Migrant Workers still occur today. Whereas national legal regulations guarantee the protection of human rights, especially nonderogable rights. This article aims to examine Indonesia's legal politics in providing nonderogable rights protection for undocumented Indonesian migrant workers. The research method uses normative juridical research. The results of this study indicate that the government has not provided optimal protection to undocumented Indonesian Migrant Workers, the government's legal politics are more optimized for prevention efforts from upstream to downstream. The state and government should be obliged to respect, protect and fulfill their human rights for Indonesian citizens, especially non-derogable rights.
\end{abstract}

Keywords: Politics of Law, Non-derogable Rights, Undocumented Indonesian Migrant Workers. 


\section{PENDAHULUAN}

Pekerja Migran Indonesia (selanjutnya disebut PMI) tidak berdokumen merupakan salah satu persoalan ketenagakerjaan yang hingga saat ini masih terjadi. Beberapa istilah yang digunakan untuk menyebut pekerja migran tidak berdokumen (undocumented migrant worker), yaitu pekerja migran tidak regular (irregular migrant), pekerja migran tidak resmi (unauthorized migrant worker), pekerja migran ilegal (illegal migrant worker), atau pendatang haram ${ }^{1}$. Badan Nasional Penempatan dan Perlindungan Tenaga Kerja Indonesia (yang selanjutnya disingkat BNP2TKI) sering menyebut dengan PMI non-prosedural. Kategori pekerja migran tidak berdokumen adalah mereka yang tidak memiliki dokumen sama sekali, memiliki dokumen namun sudah habis masa berlakunya (overstay), memakai visa wisatawan atau turis, atau menggunakan dokumen palsu. ${ }^{2}$ Data BNP2TKI per Januari hingga September 2018, mendokumentasikan 120 pengaduan PMI yang tidak berdokumen. Jumlah ini turun dibanding jumlah pengaduan tahun 2017 sebanyak 387 pengaduan dan pada tahun 2016 sejumlah 133 pengaduan. ${ }^{3}$ Permasalahan pekerja migran tidak berdokumen ini tidak hanya terjadi pada PMI, namun juga terjadi pada pekerja migran negara lain. Berdasarkan data Jabatan
Imigrasi Malaysia per 3 Juli 2018, tercatat 1.224 pendatang asing tanpa izin sudah ditangkap melalui razia. Kelompok terbesar terdiri dari pekerja migran ilegal dari Bangladesh sebanyak 399 orang, disusul Indonesia 164 orang, Filipina 157 orang dan Myanmar 109 orang. ${ }^{4}$

Dari data tersebut jumlah pekerja migran tidak berdokumen tidak sedikit. Namun perlindungan terhadap pekerja migran tidak berdokumen ini merupakan persoalan krusial, karena mereka adalah pihak yang sangat rentan terhadap pelanggaran hak-hak pekerja dan tindakan yang dapat merendahkan harkat dan martabatnya sebagai seorang manusia. Demikian juga dengan PMI tidak berdokumen. Kondisi ini dapat terlihat dengan banyaknya kasus tindakan kekerasan, eksploitasi, upah yang tidak dibayar, serta tindakan pelecehan. Banyaknya PMI tidak berdokumen berpotensi mengakibatkan tingginya pelanggaran, baik yang terjadi pada proses administrasi, pengiriman, maupun saat penempatan yang bersangkutan.

Sampai saat ini BNP2TKI tidak memiliki data pasti mengenai PMI tidak berdokumen. Diperkirakan, dari sekitar 2,7 juta PMI di Malaysia, $54 \%$ tidak berdokumen, dan dari 700.000 PMI yang ada di Arab Saudi, sekitar 400.000 orang diantaranya juga tidak berdokumen. 5 Jumlah PMI tidak berdokumen diperkirakan jauh lebih

Sefriani, 'Perlindungan HAM Buruh Migran Tak Berdokumen Berdasarkan Hukum Perdagangan dan Hukum HAM Internasional' (2013) 13 Jurnal Dinamika Hukum 245, 246.

Ibid.

BNP2TKI, 'Data Penempatan dan Perlindungan TKI Periode 1 Januari s.d. 30 April 2018' (2018) <http://www.bnp2tki.go.id/read/13234/.html> diakses 5 November 2018.

BBC Indonesia, 'Malaysia Razia Tenaga Kerja Ilegal, Sebagian TKI Bermalam di Hutan dan Kontainer' (2018) <https://www.bbc.com/indonesia/dunia-44742422> diakses 11 Oktober 2018. Robertus Belarminus, 'Alasan Kasus TKI Yang Jadi Korban Perdagangan Orang Tak Berlanjut Ke Jalur Hukum' (2018) <https://nasional.kompas.com/read/2018/04/05/17490151/alasankasus-tki-yang-jadi-korban-perdagangan-orang-tak-berlanjut-ke-jalur> diakses 11 oktober 2018. 
banyak dari data tersebut, mengingat terdapat banyak jalur ilegal pada perbatasan Indonesia dengan Malaysia. PMI tidak berdokumen biasanya baru terlacak bila tertangkap razia oleh negara penerima atau terkena permasalahan pelanggaran hak dan tindakan kejahatan. Namun perlindungan yang diperoleh para pekerja migran masih sangat terbatas. ${ }^{6}$ Pemerintah tidak dapat memberikan perlindungan secara maksimal karena lemahnya status hukum mereka. Seperti yang dialami oleh beberapa PMI di Malaysia.

Pada Februari 2018, Adelina Sau, PMI tidak berdokumen asal Nusa Tenggara Timur ini, meninggal di Penang, Malaysia, diduga Adelina dianiaya oleh majikannya. ${ }^{7}$ Demikian pula dengan yang dialami oleh Isti Komariyah pada tahun 2014, seorang PMI yang meninggal dengan berat badan hanya $26 \mathrm{~kg}$ di Malaysia, karena dibiarkan mati kelaparan oleh majikannya. ${ }^{8}$ Walaupun mengalami tindakan kekerasan dan penganiayaan oleh pemberi kerja, para PMI yang tidak berdokumen tersebut tidak berani melaporkan kepada pihak yang berwajib karena status mereka yang ilegal. Di Malaysia PMI tidak berdokumen tidak bisa mendapatkan fasilitas pengobatan di sarana kesehatan, karena Malaysia mewajibkan dokter dan penyedia sarana kesehatan untuk melaporkan orang asing yang tidak memiliki dokumen legal yang meminta bantuan kesehatan. ${ }^{9}$ Kebijakan Peme- rintah Malaysia ini di satu sisi sangat efektif untuk meminimalisir jumlah pekerja migran yang tidak berdokumen yang masuk ke negara tersebut, namun di sisi lain hal ini tidak memperhatikan sisi kemanusian pada PMI tidak berdokumen.

Dari contoh kasus di atas dapat dikatakan bahwa pelanggaran terhadap hak asasi manusia (HAM) PMI tidak berdokumen masih terus terjadi hingga saat ini. Padahal peraturan hukum nasional maupun internasional memberikan jaminan perlindungan HAM khusunya non-derogable rights kepada setiap warga negara dimanapun berada. Bahkan Indonesia juga sudah meratifikasi International Convention On The Protection of The Rights of All Migrant Workers And Members of Their Families (Konvensi Internasional Mengenai Perlindungan Hak-Hak Seluruh Pekerja Migran dan Anggota Keluarganya) yang selanjutnya disebut ICRMW dan International Covenant On Economic, Social And Cultural Rights (Kovenan Internasional tentang Hak-Hak Ekonomi, Sosial dan Budaya) yang memberikan jaminan hak asasi bagi setiap orang, termasuk PMI tidak berdokumen. Artinya, sesuai asas pacta sunt servanda Indonesia wajib melaksanakan ketentuan-ketentuan dalam instrumen hukum internasional tersebut dalam hukum nasionalnya. Secara konstitusional, Pembukaan Undang-Undang Dasar Negara Republik Indonesia (UUD NRI) Tahun 1945 menegaskan bahwa

$6 \quad$ Lalu Husni, 'Perlindungan Hukum TKI yang Bekerja di Luar Negeri (Kajian Yuridis Terhadap Sinkronisasi Peraturan Perundang-Undangan Penempatan dan Perlindungan TKI)' (2010) 2 Jurnal Hukum dan Pembangunan 270, 272.

7 Veronika Yasinta, 'Kematian TKI Adelina, Sebuah Kegagalan Melindungi Pekerja Rumah Tangga' (2018) <https://internasional.kompas.com/read/2018/02/25/14130021/> diakses 11 oktober 2018.

$8 \quad$ Ibid.

$9 \quad$ Aktieva Tri Tjitrawati, 'Perlindungan Hak dan Pemenuhan Akses Atas Kesehatan Bagi Tenaga Kerja Indonesia di Malaysia' (2017) 29 Mimbar Hukum 54, 57. 
negara melindungi segenap bangsa Indonesia dan seluruh tumpah darah Indonesia, dimana pun berada. Artinya bahwa negara juga wajib melindungi hak-hak setiap PMI tidak berdokumen dimanapun berada sebagaimana hak-hak warga negara Indonesia lainnya. Artikel ini bertujuan untuk mengkaji politik hukum perlindungan non-derogable rights $\mathrm{PMI}$ tidak berdokumen dalam semangat otonomi daerah.

Kajian dalam artikel ini menggunakan metode penelitian yuridis normatif dengan data sekunder, yang meliputi bahan hukum primer, sekunder maupun tersier yang bersumber dari berbagai buku referensi terkait dengan isu yang dikaji, peraturan perundang-undangan, karya ilmiah dan artikel terkait, serta dokumen yang berkaitan dengan materi penelitian. ${ }^{10}$ Pengumpulan bahan hukum dilakukan melalui studi kepustakaan yang kemudian diidentifikasi dan diklasifikasikan sesuai kebutuhan artikel serta disajikan secara deskriptis analitis.

\section{PEMBAHASAN}

\section{Politik Hukum dalam Perlindungan Non-Derogable Rights PMI Tidak Berdokumen}

Konsep rechtsstaat yang dikemukakan oleh Frederick Julius Stahl dalam Philosophi des Rechts, menyatakan bahwa dalam negara hukum terdapat beberapa unsur utama yaitu: (a) pengakuan dan perlindungan HAM, (b) guna melindungi HAM maka penye- lenggara negara harus berdasarkan pada teori Trias Politika, (c) pemerintah menjalankan tugasnya berdasarkan Undang-Undang (UU) (wetmatigheid van bestur), (d) apabila pemerintah dalam menjalankan tugasnya yang berdasarkan UU masih melanggar HAM, maka ada pengadilan administrasi yang akan menyelesaikannya. ${ }^{11}$ Indonesia merupakan negara hukum sehingga negara memiliki kewajiban untuk memenuhi, melindungi, dan menghormati HAM warga negara Indonesia dimanapun berada.

Negara dan pemerintah berkewajiban untuk menghormati, memenuhi, dan melindungi HAM warga negara Indonesia dimanapun berada termasuk di dalamnya adalah PMI tidak berdokumen. ICRMW menyebutkan bahwa perlindungan pekerja migran tidak hanya ditujukan kepada pekerja migran berdokumen tetapi juga untuk pekerja yang tidak berijin atau tidak berdokumen. ${ }^{12}$ Hal tersebut dapat diartikan bahwa perlindungan HAM khususnya non-derogable rights merupakan hal yang mutlak dilakukan dan diakui oleh masyarakat internasional. HAM khususnya non-derogable rights diantaranya adalah hak atas hidup, hak bebas dari penyiksaan, hak bebas dari perbudakan, hak atas perlakuan manusiawi, hak bebas dari pemidanaan yang berlaku surut, hak atas berkeyakinan dan beragama.

Politik hukum perlindungan warga negara termasuk PMI tercermin dalam konstitusi. UUD NRI Tahun 1945 menegaskan dalam Pasal 28I ayat (1) bahwa HAM yang tidak dapat dikura-

10 Soerjono Soekanto dan Sri Mamudji, Penelitian Hukum Normatif, Suatu Tinjauan Singkat (Raja Grafindo Persada 2011) 12.

11 Moh. Mahfud MD, Pergulatan Politik dan Hukum di Indonesia (Gama Media 1999) 127.

12 Pranoto Iskandar, Hukum HAM Internasional: Sebuah Pengantar Kontekstual (IMR Press 2012) 535. 
ngi dalam keadaan apapun (nonderogable rights) adalah hak untuk hidup, hak untuk tidak disiksa, hak untuk kemerdekaan pikiran dan hati nurani, hak beragama, hak untuk tidak diperbudak, hak untuk diakui sebagai pribadi dihadapan hukum, dan hak tidak dituntut atas hukum yang berlaku surut.

Politik hukum pemerintah memberikan perlindungan hukum kepada PMI dilakukan antara lain dengan mengundangkan UU No. 18 Tahun 2017 tentang Perlindungan Pekerja Migran Indonesia (UU Perlindungan PMI). Moh. Mahfud MD, berpendapat politik hukum adalah legal policy atau arah (kebijakan) hukum dapat berupa pembuatan hukum baru atau penggantian hukum lama untuk mencapai tujuan negara. ${ }^{13}$ Landasan politik hukum Indonesia adalah mewujudkan tujuan negara sebagaimana terkandung di dalam Pembukaan UUD NRI Tahun 1945, salah satu diantaranya adalah melindungi segenap bangsa Indonesia dan seluruh tumpah darah Indonesia. Pemerintah berkewajiban untuk melindungi seluruh warga negara Indonesia baik yang berada di dalam negeri maupun luar negeri, berdasarkan prinsip persamaan hak, demokrasi, keadilan sosial, kesetaraan dan keadilan gender, anti diskriminasi, dan anti perdagangan manusia. ${ }^{14}$

Selain itu, UU No. 39 Tahun 1999 tentang Hak Asasi Manusia, Pasal 2 menyebutkan Negara Republik Indonesia mengakui dan menjunjung tinggi HAM dan kebebasan dasar manusia sebagai hak yang secara kodrati melekat pada dan tidak terpisahkan dari manusia, yang harus dilindungi, dihormati, dan ditegakkan demi peningkatan martabat kemanusiaan, kesejahteraan, kebahagiaan, dan kecerdasan serta keadilan. Negara memiliki kewajiban untuk menjamin hak, kesempatan, dan memberikan perlindungan bagi setiap warga negara dimanapun berada tanpa diskriminasi untuk memperoleh pekerjaan dan penghasilan yang layak, baik di dalam maupun di luar negeri sesuai dengan keahlian, keterampilan, bakat, minat, dan kemampuan, termasuk bagi pekerja migran yang tidak berdokumen.

Dalam UU No. 18 Tahun 2017 diatur bahwa yang dimaksud dengan perlindungan pekerja migran adalah segala upaya untuk melindungi kepentingan calon PMI dan/atau PMI dan keluarganya dalam mewujudkan terjaminnya pemenuhan haknya dalam keseluruhan kegiatan sebelum bekerja, selama bekerja, dan setelah bekerja dalam aspek hukum, ekonomi, dan sosial. UU tersebut juga menegaskan bahwa perlindungan calon PMI bertujuan untuk (a) menjamin pemenuhan dan penegakan HAM sebagai warga negara dan PMI; dan (b) menjamin perlindungan hukum, ekonomi, dan sosial PMI. Pemenuhan dan penegakan HAM sebagai warga negara tersebut, seharusnya juga diberikan kepada PMI yang tidak berdokumen, khususnya nonderogable rights. Artinya, bahwa meskipun para PMI tersebut tidak berdokumen, namun non-derogable rights tetap wajib harus dipenuhi.

UU Perlindungan PMI menyebutkan bahwa setiap pekerja migran yang akan bekerja ke luar negeri harus memiliki dokumen lengkap yang dipersyaratkan. Dalam Pasal 13 diatur 
bahwa dokumen yang dimaksud adalah (a) surat keterangan status perkawinan, bagi yang telah menikah melampirkan fotokopi buku nikah; (b) surat keterangan izin suami atau istri, izin orang tua, atau izin wali yang diketahui oleh kepala desa atau lurah; (c) sertifikat kompetensi kerja; (d) surat keterangan sehat berdasarkan hasil pemeriksaan kesehatan dan psikologi; (e) paspor yang diterbitkan oleh kantor imigrasi setempat; (f) visa kerja; (g) perjanjian penempatan PMI; dan (h) perjanjian kerja. Apabila pekerja migran tidak memenuhi persyaratan tersebut, maka dapat dikatakan bahwa PMI tersebut termasuk dalam kategori tidak berdokumen. Walaupun status hukum mereka tidak berdokumen, namun PMI yang merupakan warga negara Indonesia ini harus dilindungi HAM-nya dari perdagangan manusia, perbudakan dan kerja paksa, tindak kekerasan, kesewenang-wenangan, kejahatan atas harkat dan martabat manusia, serta perlakuan lain yang melanggar HAM. Perlakuan tidak manusiawi tersebut sangat bertentangan dengan prinsip perlindungan HAM seperti yang tertuang dalam konstitusi dan konvensi internasional.

Ratifikasi Pemerintah Indonesia terhadap International Convention On The Protection of The Rights of All Migrant Workers And Members of Their Families (ICMRW) mestinya menjadi bukti komitmen pemerintah untuk memberikan jaminan perlindungan HAM bagi warga negara Indonesia yang menjadi PMI sesuai dengan standar internasional. Konvensi ini menegaskan bahwa persoalan kemanusiaan yang terkait dengan PMI menjadi lebih serius bagi PMI yang tidak berdokumen, sehingga diperlukan tindakan yang tepat dengan mendorong pencegahan dan penghapusan pengiriman dan perdagangan PMI secara gelap. Disamping itu, harus dipastikan adanya perlindungan HAM yang fundamental bagi mereka. Hal ini berarti, negara wajib untuk melakukan upaya pencegahan dan pengurangan PMI tidak berdokumen tanpa mengabaikan hak asasi yang bersifat non-derogable. Menurut Lili Rasjidi dan I. B. Wysa Putra bahwa hukum dapat difungsikan untuk mewujudkan perlindungan yang sifatnya tidak sekedar adaptif dan fleksibel, melainkan juga prediktif dan antisipatif. 15 Perlindungan hukum yang bersifat prediktif dan antisipatif artinya perlindungan hukum tersebut harus dapat memperkirakan fenomena yang akan terjadi di masa depan sehingga dapat diantisipasi tindakan yang harus dilakukan. Artinya setiap orang berhak mendapatkan perlindungan hukum, dalam rangka mewujudkan tujuan hukum yaitu nilai keadilan, kemanfaatan, dan kepastian.

Kasus yang menimpa PMI tidak berdokumen di Malaysia, Adelina Sau pada tahun 2018 dan Isti Komariyah pada tahun 2014, disamping karena mereka tidak mendapatkan pelayanan kesehatan di Malaysia, juga disebabkan karena Pemerintah Malaysia giat melakukan razia terhadap PMI tidak berdokumen. Menurut data dari imigrasi, PMI yang dipulangkan karena tidak memiliki dokumen resmi untuk bekerja di Malaysia, pada bulan Agustus 2018 terdapat sebanyak 139 PMI bermasalah yang dideportasi dari Malaysia lewat Pelabuhan Sri Bintan

15 Hidayat, 'Perlindungan Hak Tenaga Kerja Indonesia Di Taiwan dan Malaysia Dalam Perspektif Hak Asasi Manusia' (2017) 8 Jurnal HAM 105, 111. 
Pura (SBP) Tanjungpinang. ${ }^{16}$ Kemudian pada November 2018, Direktorat Polisi Air dan Udara (Ditpolairud) Polda Kepri mengamankan 24 PMI ilegal yang akan berangkat ke Malaysia melalui jalur ilegal. 17

Malaysia merupakan salah satu negara tujuan PMI tidak berdokumen, karena letak geografisnya yang dekat dengan Indonesia sehingga sangat memungkinkan banyak ditemukannya jalur-jalur ilegal di perbatasan. Lebih dari 50\% PMI di Malaysia tidak memiliki dokumen resmi (undocumented).

Penyelesaian permasalahan PMI tidak berdokumen ini, masih menemui berbagai kendala yang timbul tidak hanya berkenaan dengan peraturanperaturan namun juga buruknya pelaksanaan penempatan PMI. Kasus pelanggaran HAM yang terjadi terhadap PMI di Malaysia tidak terlepas dari pelaku yang terlibat di dalamnya, yakni aktor negara dan aktor non negara. Pejabat pembuat KTP dan pejabat pembuat paspor terlibat dalam tindak pemalsuan dokumen pekerja migran. ${ }^{18}$ Kemudian banyaknya calo yang menghubungkan pemberi kerja dengan PMI tidak berdokumen agar dapat bekerja di luar negeri. Selain itu, keterlibatan negara dalam perlindungan PMI yang relatif lemah, karena diserahkan kepada penyalur pekerja migran.
Pemerintah telah melakukan pertemuan bilateral dengan Malaysia untuk menangani dan mencegah praktik PMI tidak berdokumen. Pertemuan bilateral tersebut menghasilkan penandatanganan Letter of Intent (LoI) dalam pelaksanaan kerja sama rekrutmen dan penempatan PMI di Malaysia melalui sistem satu channel. ${ }^{19}$ LoI ditandatangani oleh M. Hanif Dhakiri, Menteri Ketenagakerjaan Indonesia dan Dato' Sri Richard Riot Anak Jaem Menteri Sumber Manusia Malaysia di Putrajaya, Malaysia pada bulan September 2016 lalu. Sistem satu channel yang dimaksud adalah informasi lowongan kerja di luar negeri harus disahkan otoritas ketenagakerjaan kedua negara pihak, sehingga PMI dapat terhindar dari calo penipuan dan negara penerima PMI tidak dapat mempekerjakan PMI tidak berdokumen. Sistem tersebut bertujuan untuk memberikan perlindungan PMI dan mencegah praktek perdagangan manusia dan PMI tidak berdokumen. Selain itu, KBRI di Kuala Lumpur, Malaysia juga melakukan upaya perlindungan terhadap PMI bermasalah dengan cara rescue (melakukan penyelamatan terhadap PMI tidak berdokumen yang mengalami permasalahan), shelter (membuat tempat penampungan sementara), bantuan hukum kepada PMI, dan kemudian repratiasi bila diperlukan. ${ }^{20}$

16 Muhammad Bunga Ashab, '139 TKI Ilegal Dideportasi dari Malaysia, Beberapa Orang Sempat Dipenjara' (2018) <https://news.okezone.com/read/2018/08/01/340/1930554/139-tki-ilegaldideportasi-dari-malaysia-beberapa-orang-sempat-dipenjara> diakses 20 Desember 2018.

17 Veronika Yasinta, Op.Cit.

18 Desideria Talitha DS, 'Pelanggaran Hak Asasi Manusia (HAM) Terhadap Tenaga Kerja Indonesia (TKI) Di Malaysia Tahun 2011-2013' (2016) 2 Journal of International Relations 11, 13.

19 Muhammad Khamdi, 'RI-Malaysia Sepakati Perlindungan TKI' (2016) <https://ekonomi. bisnis.com/read/20160923/12/586623/ri-malaysia-sepakati-perlindungan-tki> diakses 13 Februari 2019.

20 Taufan Herdiansyah Akbar, Suwarti Sari, dan Aliesa Amanita, 'Implementasi Kebijakan Pemerintah Dalam Perlindungan Tenaga Kerja Wanita (TKW) Studi Kasus: TKW Di Malaysia' (2017) 2 Dinamika Global Jurnal Ilmu Hubungan Internasional 23, 37. 
Indonesia berkewajiban untuk menghormati, melindungi dan memenuhi hak-hak setiap warga negara baik yang ada di dalam wilayahnya maupun yang berada di luar negara. Hal ini sesuai dengan prinsip yurisdiksi personal, dimana negara berkewajiban untuk memberikan perlindungan diplomatik kepada warga negaranya di luar negeri dan negara memiliki yurisdiksi terhadap warga negaranya yang menjadi korban kejahatan di luar negeri berdasarkan Prinsip Nasionalitas Pasif. ${ }^{21}$

Kewajiban menghormati ini berarti bahwa negara menjamin agar kebijakannya tidak melanggar HAM warga negaranya. Sedangkan kewajiban negara untuk melindungi dapat dilakukan dengan mencegah setiap pelanggaran yang dilakukan oleh pihak ketiga dan melakukan penyelidikan dan penghukuman bagi yang melanggar. Sementara itu kewajiban negara untuk memenuhi meletakkan kewajiban agar negara menciptakan kondisi yang memungkinkan setiap individu menikmati haknya, misalnya terkait hak atas pekerja dengan penyediaan informasi pekerjaan atau menciptakan lapangan pekerjaan. ${ }^{22}$

Politik hukum pemerintah adalah melakukan upaya-upaya pencegahan adanya PMI tidak berdokumen dengan mengeluarkan regulasi perlindungan PMI dengan memaksimalkan peran pemerintah daerah. Pemerintah juga selalu berusaha ikut mendampingi PMI tidak berdokumen yang terkena permasalahan hukum di luar negeri, sebagai contoh pendampingan hukum kasus Eti binti Toyib, PMI di Arab Saudi yang terkena qisos 20 milyar rupiah, pemerintah juga melakukan pendampingan hukum bagi keluarga Adelina yang meninggal di Malaysia beberapa waktu lalu. Namun, perlindungan yang diberikan pemerintah bisa dikatakan masih lemah. Pemerintah Indonesia belum meratifikasi Konvensi Pekerja Migran dan Penyelesaian Perselisihan Buruh karena pertimbangan hak-hak pekerja asing yang bekerja di Indonesia. ${ }^{23}$ Pemerintah Indonesia belum bisa memberikan hak-hak pekerja asing yang bekerja di Indonesia sesuai dengan konvensi tersebut.

Adanya perbedaan kepentingan antara negara penerima dan negara pengirim PMI dapat menimbulkan hambatan dalam perlindungan PMI yang bermasalah. Malaysia sebagai negara penerima PMI ternyata belum meratifikasi ICRMW. Artinya Pemerintah Malaysia tidak dapat dituntut memberikan perlindungan hak-hak PMI yang tidak berdokumen di Malaysia berdasarkan Konvensi tersebut. Perlindungan PMI merupakan bagian dari penegakan HAM. Namun demikian, bukan berarti bahwa Pemerintah Malaysia dapat mengesampingkan perlindungan PMI tidak berdokumen di negaranya, karena kewajiban negara ini tidak hanya bersumber dari konvensi internasional namun juga berasal dari nilai-nilai

21 Dian Khoreanita Pratiwi dan Wahyu Nugroho, 'Implementasi Yurisdiksi Negara Indonesia Dalam Pemberantasan Perompakan Dan Perampokan Laut Berdasarkan Hukum Internasional' (2017) 2 2 Era Hukum Jurnal Ilmiah Ilmu Hukum 1, 6.

22 Margaret L.Satterthwaite dalam Sri Lestari Rahayu, Siti Muslimah, dan Sasmini, 'Perlindungan Ham Pekerja Migran: Kajian Normatif Kewajiban Indonesia Berdasar Prinsip-Prinsip Dan NormaNorma Hukum Internasional' (2013) 2 Yustisia Jurnal Hukum 111, 112.

23 Dwi Wahyu Handayani, Agus Hadiawan, dan Aman Toto Dwijono, 'Dinamika Kerjasama Indonesia dan Malaysia tentang Penempatan dan Perlindungan Tenaga Kerja' (2015) 17 Jurnal Sosiologi 31, 36-37. 
yang mendasari keberadaan masyarakat internasional (jus cogens) yang melahirkan kewajiban dasar dalam masyarakat internasional bahwa penghormatan terhadap hak asasi setiap orang merupakan bagian dari kewajiban negara (obligation erga omnes).

Pasal 21 huruf $d$ dan $f$ UU Perlindungan PMI menegaskan bahwa perlindungan selama bekerja yang diperoleh oleh seorang PMI selama bekerja di luar negeri antara lain meliputi fasilitasi penyelesaian kasus ketenagakerjaan, pendampingan, mediasi, dan advokasi. PMI yang bermasalah berhak mendapatkan bantuan hukum berupa fasilitasi jasa advokat oleh Pemerintah Pusat dan/atau Perwakilan Republik Indonesia serta perwalian sesuai dengan hukum setempat. Namun secara tersurat, jaminan hukum perlindungan dalam UU tersebut hanya diberikan, kepada pekerja migran legal atau berdokumen selama masih bekerja.

Terkait dengan kewajiban pemerintah menekan jumlah dan mencegah PMI yang tidak berdokumen atau ilegal bekerja di luar negeri, maka ketentuan Pasal 70 UU Perlindungan PMI menentukan bahwa setiap pejabat dilarang memberangkatkan PMI yang tidak memenuhi persyaratan kelengkapan dokumen. UU tersebut juga menegaskan bahwa pekerja yang dapat ditempatkan di luar negeri adalah PMI yang telah memenuhi persyaratan dokumen sebagaimana dimaksud dalam Pasal 13. Pemberian sanksi pidana diberikan kepada orang yang menempatkan pekerja migran tidak berdokumen yang tidak memenuhi persyaratan tersebut, sebagaimana dalam Pasal 83 dan Pasal 84 UU Perlindungan PMI. Hal ini sesuai dengan UU No. 21 Tahun 2007 tentang
Tindak Pidana Perdagangan Orang, bahwa setiap orang yang membawa WNI ke luar negeri dengan tujuan untuk dieksploitasi maka akan dijerat dengan UU ini.

Pemberian sanksi pidana terhadap orang yang memberangkatkan PMI tidak berdokumen, merupakan bentuk tindakan pemerintah untuk memberikan perlindungan terhadap PMI dan mencegah terjadinya penyelundupan PMI. Namun, UU Perlindungan PMI hanya memberikan perlindungan hukum kepada PMI yang telah memenuhi persyaratan dokumen. Bagi PMI yang tidak berdokumen ternyata belum diatur secara jelas bagaimana perlindungan hukum mereka apabila terjadi permasalahan ketenagakerjaan dan pelanggaran HAM mereka selama berada di luar negeri. Perlindungan hukum yang dimaksud adalah perlindungan hukum sebagai warga negara, agar hak asasinya tidak terlanggar lebih jauh. Perlindungan hukum tersebut tidak menjadikan PMI tidak berdokumen menjadi memiliki hak yang sama dengan PMI berdokumen. UU tersebut belum memberikan perlindungan dan penanganan yang baik terhadap PMI yang tidak berdokumen, padahal pemerintah sudah meratifikasi Konvensi Internasional Mengenai Perlindungan Hak-Hak Seluruh Pekerja Migran dan Anggota Keluarganya. Sesuai dengan asas pacta sunt servanda, mestinya konvensi internasional tersebut menjadi acuan dalam memberikan perlindungan kepada PMI dimanapun berada, baik yang berdokumen lengkap maupun tidak berdokumen agar tetap terpenuhi HAM mereka.

Prinsip equality before the law, equal protection dan non discrimination harusnya juga berlaku bagi PMI tidak 
berdokumen, karena pada dasarnya hukum internasional tidak mengijinkan adanya perlakuan diskriminatif atas dasar kewarganegaraan ataupun status keimigrasiannya. ${ }^{24}$ Prinsip equality before the law, equal protection dan non discrimination harus diterapkan kepada setiap manusia tidak terkecuali bagi PMI tidak berdokumen. Terlepas dari status mereka yang tidak berdokumen, tidak menjadikan mereka boleh direnggut hak-hak asasi yang tidak dapat dikurangi sebagai manusia (non-derogable rights).

Dalam pembukaannya, ICMRW berkomitmen untuk mencegah dan menghapuskan perdagangan pekerja migran ilegal dan memastikan adanya perlindungan HAM mereka. Pekerja yang tidak memiliki dokumen atau dalam situasi tak reguler seringkali dipekerjakan kurang layak. Penerima kerja juga cenderung mempekerjakan mereka karena upah yang murah. ICRMW bertujuan untuk melindungi hak dasar pekerja migran dan anggota keluarganya.

Pasal 5 ICMRW, mengakui adanya pekerja migran yang tidak berdokumen atau berada dalam situasi tak regular, sehingga dalam ICMRW dilakukan berbagai upaya untuk mencegah masuknya pekerja tidak berdokumen, salah satunya dengan menentukan kebijakan-kebijakan yang harus diambil oleh negara-negara pihak dan pemberian sanksi kepada pelaku yang menggunakan pekerja migran tidak berdokumen. Kebijakan yang dikeluarkan negara-negara pihak tidak boleh merugikan hak-hak pekerja migran yang muncul karena pekerjaan mereka. Dapat disimpulkan bahwa ICMRW menghendaki adanya perlindungan bagi pekerja migran dan anggota keluarganya dan mencegah terjadinya pekerja migran tidak berdokumen.

\section{Keterlibatan Pemerintah Daerah dalam Mencegah Adanya PMI Tidak Berdokumen}

Perkembangan ekonomi di daerah dinilai belum cukup untuk meningkatkan kesejahteraan masyarakat, sehingga tidak mampu menahan keinginan masyarakat untuk mencari pekerjaan dengan penghasilan yang layak dengan menjadi PMI. Situasi tersebut mendorong tingginya angka PMI yang berangkat melalui jalur ilegal. Hal ini didukung oleh banyaknya rekruitmen masif yang dilakukan para calo, yang faktanya mereka ini minim melakukan sosialisasi untuk memberikan informasi kepada para calon PMI, seringkali melakukan pemalsuan dokumen para calon PMI dengan pembebanan biaya yang cukup mahal, serta koordinasi dengan instansi terkait yang tidak kuat.

UU No. 23 Tahun 2014 tentang Pemerintahan Daerah mengamanatkan bahwa urusan tenaga kerja termasuk pekerja migran juga menjadi tanggung jawab pemerintah daerah. Terkait dengan perlindungan PMI, maka pemerintah daerah berperan aktif dalam menangani permasalahan PMI, terutama bagi pemerintah daerah yang menjadi kantong-kantong pengiriman PMI. Kebutuhan ekonomi dan harapan gaji yang tinggi menyebabkan tingginya animo untuk bekerja keluar negeri. Para calon PMI seringkali menghalalkan segala cara agar dapat bekerja di luar negeri dan mengabaikan pertimbangan risiko yang mungkin menimpa mereka saat bekerja.

24 Sefriani., Op.Cit., 252. 
Sesuai dengan Pasal 42 UU Perlindungan PMI, pemerintah daerah berwenang menerima dan memberikan informasi permintaan (job order) kepada masyarakat, melakukan verifikasi data dan pencatatan calon PMI, memfasilitasi pemenuhan persyaratan administrasi kependudukan calon PMI, melakukan pemantauan keberangkatan dan kepulangan PMI, termasuk, memberdayakan calon pekerja migran, pekerja migran, dan anggota keluarganya.

Pasal 40 UU Perlindungan PMI mengatur tentang tanggung jawab pemerintah daerah provinsi untuk menyelenggarakan pendidikan dan pelatihan kerja bagi calon PMI; mengurus kepulangan PMI dalam hal terjadi peperangan, bencana alam, wabah penyakit, deportasi, dan ketika PMI menghadapi masalah; menerbitkan izin perusahaan penempatan dan melaporkan hasil evaluasi terhadap kinerja perusahaan secara berjenjang dan periodik kepada menteri; menyediakan pos bantuan, pelayanan pemulangan dan pemberangkatan, menyediakan dan memfasilitasi pelatihan vokasi calon pekerja migran yang anggarannya dari fungsi pendidikan; mengatur, membina, melaksanakan, dan mengawasi penyelenggaraan penempatan pekerja migran; dan membentuk Layanan Terpadu Satu Atap (LTSA) penempatan dan perlindungan PMI.

Adapun tugas dan tanggung jawab pemerintah daerah kabupaten/ kota terhadap PMI diatur dalam Pasal 41 UU Perlindungan PMI, sebagai berikut:

a. mensosialisasikan informasi dan permintaan kepada masyarakat;

b. membuat basis data PMI;

c. melaporkan hasil evaluasi terhadap perusahaan PMI secara perio- dik kepada pemerintah daerah provinsi;

d. mengurus kepulangan PMI dalam hal terjadi peperangan, bencana alam, wabah penyakit, deportasi, dan ketika PMI menghadapi masalah sesuai kewenangannya;

e. memberikan perlindungan PMI sebelum dan setelah bekerja di daerah kabupaten/ kota sesuai kewenangannya;

f. menyelenggarakan serta melakukan pembinaan dan pengawasan terhadap lembaga pendidikan dan pelatihan kerja bagi calon PMI;

g. melakukan reintegrasi sosial dan ekonomi bagi pekerja migran dan keluarganya;

h. menyediakan dan memfasilitasi pelatihan vokasi calon pekerja migran yang anggarannya dari fungsi pendidikan;

i. mengatur, membina, melaksanakan, dan mengawasi penyelenggaraan penempatan pekerja migran; serta

j. membentuk layanan terpadu satu atap penempatan dan perlindungan PMI di tingkat kabupaten/ kota.

Untuk mencegah PMI tidak berdokumen, pemerintah daerah terus mengembangkan inovasi pelayanan yang ramah dan cepat, yaitu dengan dibentuknya LTSA. Direktur Penempatan dan Perlindungan Tenaga Kerja Luar Negeri, Soes Hindharno, menyatakan bahwa telah dibentuk 23 LTSA 
di seluruh Indonesia. ${ }^{25}$ Pembentukan LTSA ini bertujuan memberikan pelayanan adminisitrasi secara singkat, efektif, dan efisien bagi para calon pekerja migran, perusahaan penempatan pekerja migran, dan instansi terkait lainnya. Melalui perbaikan tata kelola layanan ini diharapkan calon PMI dapat melalui proses rekrutmen, pelatihan, penempatan, perlindungan, dan pemulangan secara resmi. LTSA dibentuk untuk memperkecil peluang terjadinya PMI tidak berdokumen.

Dengan melaksanakan dan memaksimalkan tugas dan tanggung jawab pemerintah daerah diharapkan dapat membantu pemerintah pusat dalam menyelesaikan berbagai permasalahan PMI yang bekerja di luar negeri termasuk di dalamnya mengenai pekerja migran ilegal atau tidak berdokumen. Pada hakikatnya PMI ilegal atau tidak berdokumen juga merupakan warga negara Indonesia yang wajib dilindungi dan dijamin dalam pemenuhan hak-hak asasi manusianya khususnya non-derogable rights.

\section{PENUTUP}

Permasalahan PMI yang masih menjadi persoalan utama adalah PMI tidak berdokumen. PMI tidak berdokumen ini rentan terhadap tindakan kejahatan dan pelanggaran hak asasinya khususnya nonderogable rights. Kondisi ini dapat terlihat dengan banyaknya kasus tindakan kekerasan, eksploitasi, upah yang tidak dibayar, serta tindakan pelecehan. Pelanggaran terhadap hakhak asasi manusia bagi PMI tidak berdokumen ini masih terus terjadi hingga saat ini. Padahal dalam konstitusi dan peraturan hukum nasional memberikan jaminan perlindungan HAM (non-derogable rights) kepada setiap warga negara di manapun ia berada.

Politik hukum pemerintah untuk mencegah adanya PMI tidak berdokumen, diantaranya melakukan kerja sama dengan Pemerintah Malaysia dan mengundangkan UU Perlindungan PMI. Peraturan ini memaksimalkan tugas dan tanggung jawab pemerintah daerah yang diharapkan dapat membantu pemerintah pusat dalam menyelesaikan berbagai permasalahan PMI termasuk yang tidak berdokumen. Pemerintah daerah bertanggung jawab dan berperan aktif menekan jumlah PMI tidak berdokumen, karena pada hakikatnya PMI tidak berdokumen juga merupakan warga negara Indonesia yang wajib dilindungi dan dijamin dalam pemenuhan hak-hak asasi manusianya khususnya non-derogable rights.

\section{DAFTAR BACAAN}

\section{Buku}

Iskandar, P., Hukum HAM Internasional: Sebuah Pengantar Kontekstual (IMR Press 2012).

MD, Moh. M., Pergulatan Politik dan Hukum di Indonesia (Gama Media 1999).

MD, Moh. M., Politik Hukum di Indonesia (Rajawali Pers 2014).

Soekanto, S., dan Mamudji, S., Penelitian Hukum Normatif, Suatu Tinjauan Singkat (Raja Grafindo Persada 2011).

25 Moch Prima Fauzi, Lindungi TKI Kemnaker Bangun Layanan Terpadu Satu Atap Di Kendal' (2018) <https:/ finance.detik.com/berita-ekonomi-bisnis/d-3966701/lindungi-tki-kemnaker-bangunlayanan-terpadu-satu-atap-di-kendal> diakses 13 Februari 2019. 


\section{Artikel Jurnal}

Akbar, Taufan H., Sari, S., dan Aliesa, A., Implementasi Kebijakan Pemerintah Dalam Perlindungan Tenaga Kerja Wanita (TKW) Studi Kasus: TKW Di Malaysia (2017) 2 Dinamika Global Jurnal Ilmu Hubungan Internasional.

DS, Desideria T., 'Pelanggaran Hak Asasi Manusia (HAM) Terhadap Tenaga Kerja Indonesia (TKI) Di Malaysia Tahun 2011-2013' (2016) 2 Journal of International Relations.

Handayani, Dwi W., Hadiawan, A., dan Dwijono, Aman T., 'Dinamika Kerjasama Indonesia dan Malaysia tentang Penempatan dan Perlindungan Tenaga Kerja' (2015) 17 Jurnal Sosiologi.

Hidayat, 'Perlindungan Hak Tenaga Kerja Indonesia Di Taiwan Dan Malaysia Dalam Perspektif Hak Asasi Manusia' (2017) 8 Jurnal HAM.

Husni, L., 'Perlindungan Hukum TKI yang Bekerja di Luar Negeri (Kajian Yuridis Terhadap Sinkronisasi Peraturan Perundang-Undangan Penempatan dan Perlindungan TKI)' (2010) 2 Jurnal Hukum dan Pembangunan.

Rahayu, Sri L., Muslimah, S., dan Sasmini, 'Perlindungan HAM Pekerja Migran: Kajian Normatif Kewajiban Indonesia Berdasar Prinsip-Prinsip dan Norma-Norma Hukum Internasional' (2013) 2 Yustisia Jurnal Hukum.

Sefriani, 'Perlindungan HAM Buruh Migran Tak Berdokumen Berdasarkan Hukum Perdagangan dan Hukum HAM Internasional' (2013) 13 Jurnal Dinamika Hukum.
Tjitrawati, Aktieva T., 'Perlindungan Hak dan Pemenuhan Akses Atas Kesehatan Bagi Tenaga Kerja Indonesia di Malaysia' (2017) 29 Mimbar Hukum.

Pratiwi, Dian K., dan Nugroho, W., 'Implementasi Yurisdiksi Negara Indonesia Dalam Pemberantasan Perompakan dan Perampokan Laut Berdasarkan Hukum Internasional' (2017) 2 Era Hukum Jurnal Ilmiah Ilmu Hukum.

\section{Internet}

Ashab, Muhammad B., '139 TKI Ilegal Dideportasi dari Malaysia, Beberapa Orang Sempat Dipenjara' (2018), <https:// news.okezone. $\mathrm{com} / \mathrm{read} / 2018 / 08 / 01 / 340 / 193$ 0554/139-tki-ilegal-dideportasi-d ari-malaysia-beberapa-orang-sem pat-dipenjara $>$ diakses 20 Desember 2018.

BBC Indonesia, 'Malaysia Razia Tenaga Kerja Ilegal, sebagian TKI Bermalam di Hutan dan Kontainer' (2018) <https://www.bbc.com/ indonesia/dunia-44742422> diakses 11 Oktober 2018.

Belarminus, R., 'Alasan Kasus TKI yang Jadi Korban Perdagangan Orang Tak Berlanjut ke Jalur Hukum' (2018) <https://nasion al.kompas.com/read/2018/04/05 / 17490151/alasan-kasus-tki-yan g-jadi-korban-perdagangan-orang -tak-berlanjut-ke-jalur> diakses 11 oktober 2018.

BNP2TKI, 'Data Penempatan dan Perlindungan TKI Periode 1 Januari S.D 30 April 2018' (2018) <http://www.bnp2tki.go. id/read/ 13234/html> diakses 5 November 2018. 
Fauzi, Moch P., 'Lindungi TKI

Kemnaker Bangun Layanan Terpadu Satu Atap Di Kendal' (2018) <https:/ / finance.detik. com /berita-ekonomi-bisnis /d-396670 1/lindungi-tki-kemnaker-bangunlayanan-terpadu-satu-atap-di-ken dal> diakses 13 Februari 2019.

Khamdi, M., 'RI-Malaysia Sepakati Perlindunga TKI' (2016) <https: //ekonomi.bisnis.com/read/2016 0923/12/586623/ri-malaysia-sep akati-perlindungan-tki> diakses 13 Februari 2019.

Yasinta, V., 'Kematian TKI Adelina, Sebuah Kegagalan Melindungi Pekerja Rumah Tangga' (2018) <https: / / internasional.kompas.co $\mathrm{m} / \mathrm{read} / 2018 / 02 / 25 / 1413002 / \mathrm{k}$ ematian-tki-adelina-sebuah-kega galan-melindungi-pekerja-rumahtangga> diakses 11 oktober 2018.

\section{Peraturan Perundang-Undangan}

Undang-Undang Dasar Negara Republik Indonesia Tahun 1945.

Undang-Undang Nomor 39 Tahun 1999 tentang Hak Asasi Manusia.

Undang-Undang Nomor 6 Tahun 2012 tentang Pengesahan International Convention On The Protection of The Rights of All Migrant Workers And Members of Their Families.

Undang-Undang Nomor 23 Tahun 2014 tentang Pemerintahan Daerah.

Undang-Undang Nomor 18 Tahun 2017 tentang Perlindungan Pekerja Migran Indonesia. 